\title{
THE IMPACT OF HAVING CHILDREN ON PARTY MEMBER ACTIVISM
}

\begin{abstract}
Party member activism varies in type and intensity, and it is necessary to take this into consideration when explaining the degree of participation. One potential explanation for the level of party member participation is the extent to which there are children in the household. Based on the Danish party member survey of 2012, analyses show: First, the cost of having children is more important when explaining more demanding activities than the less demanding activities, and, second, the impact of the cost of having children in the household is larger when including the intensity of participation in the dependent variable. Third, the smaller the children, the larger the cost and the larger the negative impact on party activism no matter what type or intensity. Furthermore, there are only limited gender differences in the impact of having children so that children, in particular in the young age group, do not have a larger impact on women than men, except when it comes to meeting attendance. In sum, children do have an impact on party member activism, and the gender gap in this effect is very limited.
\end{abstract}

\section{Key words}

Party membership, party organization, gender differences, political participation, family

* Karina Kosiara-Pedersen, Department of Political Science, University of Copenhagen, Denmark, kp@ifs.ku.dk. 